\title{
Measuring Traffic Induced Air Pollution in Onne Port's Environment
}

\section{Donatus Eberechukwu Onwuegbuchunam1, Famous Egelu², Moses Olatunde Aponjolosun1, Kenneth Okechukwu Okeke ${ }^{1}$}

${ }^{1}$ Department of Maritime Management Technology, Federal University of Technology Owerri, Imo State, Nigeria

${ }^{2}$ Department of Maritime Transport \& Logistics, Nigerian Maritime University Okerenkeko, Warri, Delta State

Email: don@futo.edu.ng

How to cite this paper: Onwuegbuchunam, D.E., Egelu, F., Aponjolosun, M.O. and Okeke, K.O. (2021) Measuring Traffic Induced Air Pollution in Onne Port's Environment. Open Journal of Air Pollution, 10, 63-75.

https://doi.org/10.4236/ojap.2021.104005

Received: August 12, 2021

Accepted: September 15, 2021

Published: October 1, 2021

Copyright (c) 2021 by author(s) and Scientific Research Publishing Inc. This work is licensed under the Creative Commons Attribution International License (CC BY 4.0).

http://creativecommons.org/licenses/by/4.0/

\begin{abstract}
Maritime shipping has been a major facilitator of economic prosperity throughout the world and it is likely to grow to meet continued and growing transport needs in both developed and developing countries. However, global emissions from maritime shipping have increased considerably, causing depletion of the ozone layer and most importantly posing threat to lives and coastal environment through air pollution. This study investigated the constituents of ambient air in Onne port's environment in Rivers State of Nigeria. Six air pollutants $\left(\mathrm{O}_{3}\right.$ $\mathrm{CO}, \mathrm{NO}_{2}, \mathrm{PM}_{2.5}, \mathrm{PM}_{10}$, and $\mathrm{SO}_{2}$ ) were critically monitored with hand-held mobile Aeroqual gas monitors, series 500, at strategic locations within the port's environment and Eleme Junction (the control). We found that mean concentrations $\left(\mu \mathrm{g} \cdot \mathrm{m}^{3}\right)$ of the following pollutants: $\mathrm{O}_{3}(71.776 \pm 0.726), \mathrm{CO},(19.145 \pm$ $0.275) \mathrm{NO}_{2}(28.145 \pm 0.965)$ and $\mathrm{SO}_{2}(36.913 \pm 0.378)$ were significantly high. The particulates $\left(\mathrm{PM}_{10}, \mathrm{PM}_{2.5}\right)$ also showed higher mean concentrations of $48.400 \pm 0.197$ and $29.676 \pm 0.352$ respectively. The observed values were found to be significantly higher than those observed in the control group and also exceeded the safe permissible limits for gaseous pollutants when compared to the World Health Organization's (WHO) standards. This exceedance raises questions on Nigeria's commitments to implementations of (Annex VI) International Maritime Organization's (IMO) Convention for the Prevention of Marine Pollution (MARPOL 73/78) from Ships. Again, the findings portend ecological hazards to residents, flora and fauna as elevated levels of these gaseous pollutants have been associated with chronic respiratory diseases. The policy implications of the findings were discussed.
\end{abstract}

\section{Keywords}

Air Pollution in Ports, Greenhouse Gases, Health Hazards, Ozone Layer, 


\section{Introduction}

Increasing demand for seaborne transport has given rise to increased shipping activities globally (UNCTAD [1]). However, the increase in shipping activities has made shipping sector one of the most polluting industries. Seaports play a significant role in shipping operations as they serve as platforms where seaborne import and export activities are carried out. The study by Nicolae et al. [2] posits that maritime transportation contributes immensely to air pollution especially in seashore areas. It should be noted that seaports located mostly in urban and close to residential areas are considered as the major sources of environmental pollution affecting air quality with dire consequences on human health (Bermudez et al. [3]; Tokuslu [4]). Cancer of the lungs, asthma, bronchitis, premature death and other respiratory and cardiovascular diseases are some of the health impacts of pollutions at seaports (Tokuslu [4], Eyring, et al., [5]; Song \& Shon, [6]). It is pertinent to note that the need to protect people and their socio-economic activities (Olukanni and Esu [7]) in the port environment is gaining more attention considering the environmental and health impacts of maritime traffic emissions in and around the ports. Emissions of the following pollutants, namely: Particulate matter, Sulphur Oxides $\left(\mathrm{SO}_{\mathrm{x}}\right)$, Nitrogen Oxides $\left(\mathrm{NO}_{\mathrm{x}}\right)$, volatile organic compounds (VOC) and Carbon dioxide $\left(\mathrm{CO}_{2}\right)$ have been linked to increased ground level ozone, acidification, eutrophication, corrosion and climate change. The International Maritime Organization's (IMO) greenhouse gases (GHGs) emission study (for the year 2012) found significant percentages of $\mathrm{CO}_{2}$ (796 million tonnes) and 816 million combined tonnes of $\mathrm{CO}_{2}, \mathrm{CH}_{4}$ and $\mathrm{N}_{2} \mathrm{O}$ emissions arising from international shipping operations (Smith et al., [8]). Concerned with these ship-fossil fuel emissions and impacts on climate change, The United Nations Conference on Environment and Development (UNCED) held at Rio de Janeiro in 1992 advocated for use of alternative energy sources to replace the use of fossil fuels. This measure was further strengthened through ship emission targets set by the United Nations Framework Convention on Climate Change (UNFCCC). IMO consolidated these efforts with further amendments to Annex VI of MARPOL 73/78 which require all new-build ships to comply with the Energy Efficiency Design Index (EEDI), and for all new and existing ships to have a ship specific Ship Energy Efficiency Management Plan (SEEMP), targeting ship operational energy efficiency (IMO, [9]). These operational measures are meant to promote efficient use of energy on board vessels and thus minimize air pollutants emissions. Amendments to Annex VI of MARPOL also provide for limits on use of the sulphur contents of marine fuels powering marine vessels. Use of scrubbers is also advocated for which should be fitted on ship ex- 
hausts to limit Sulphur emissions.

There have been several studies on air pollution in Nigeria; notable ones include: Nwachukwu et al., [10] who examined the effect of air pollution diseases on persons living in Rivers State using epidemiological data collected from the State's Ministry of Health. The result showed that air pollution had a direct impact on health of the residents. Olayinka et al., [11] investigated air pollutants such as $\mathrm{CO}_{2}, \mathrm{NO}_{2}, \mathrm{CO}, \mathrm{NO}_{2}, \mathrm{H}_{2} \mathrm{~S}$ and suspended Particulate Matter arising from vehicular emissions in Abeokuta metropolis. Abulude et al., [12] carried out a preliminary assessment of air quality levels in Lagos state. Air quality and meteorological parameters of five locations in the state were monitored and data collected were statistically analyzed. In respect to operations in ports, Olukanni and Esu [7] estimated the amount of greenhouse gases (GHGs) emitted from vessel operations in Tincan Island and Apapa ports in Lagos state. Also, Jimoda et al., [13] carried out a study on emission inventory using emission factor approach to quantity the criteria of air pollutants emanating from ships at Tincan Island seaport in Nigeria. The results of their study revealed that $\mathrm{NO}_{\mathrm{x}}$ constituted the highest percentage of $79 \%$ followed by $\mathrm{SO}_{2}, \mathrm{PM}$ and $\mathrm{CO}$ with $10 \%, 6 \%$ and $5 \%$ respectively. In the present paper, we investigate the constituents of air pollution in port environment and relate results with traffic activity levels especially the following: volume of shipping and land transport activity levels within the port. The important gap to be filled by this research is the investigation of emissions arising from international and domestic shipping traffic and freight movements as well as other shipping activities within the Onne port area. The concentration levels of Greenhouse gases (GHGs) and other pollutant emissions in the port environment will be estimated with the help of a hand held mobile aerosol gas monitors; series 500. Moreover, this study will be of great significance to the general public, especially port regulators by providing scientific information on ship emissions in the port of Onne. The results should serve as basis for designing administrative measures to reduce the level of air pollutants emissions at the ports.

\section{Research Methodology}

The study was carried out in Onne port, Nigeria. The port is located in the bonny river estuary along Ogu creek. Onne port is run on landlord model to encourage private sector participation in the port industry. Onne port houses one of the largest oil and gas free zones in the world which support exploration and production activities in Nigeria; providing logistics support for both onshore and offshore oil and gas industry. Numerous operations such as handling of general cargo, oil-well equipment, containerized cargoes and other logistics services are carried out in the port. Hence the port is a multi-purpose cargo port. The port covers an area of 2,538.115 hectares. Figure 1 shows the map of the study area. 


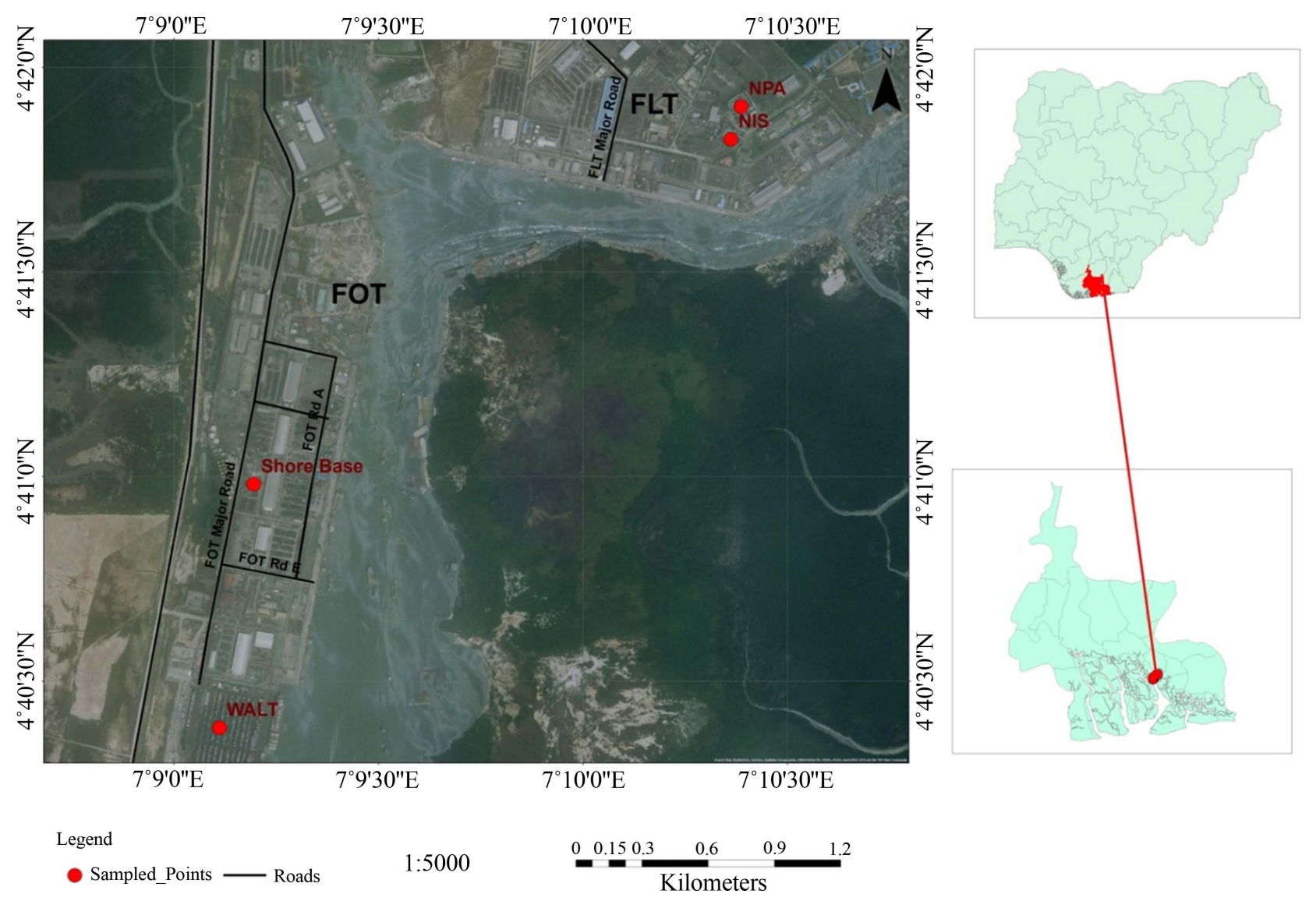

Figure 1. The map of the study area showing the sampling locations.

\subsection{Equipment Used}

Hand-held mobile Aeroqual gas monitors; series 500 (Figure 2) was used to detect the presence and precise quantity of the following individual gases:

- Sulfur Dioxide $\left(\mathrm{SO}_{2}\right)$

- Nitrogen Dioxide $\left(\mathrm{NO}_{2}\right)$

- Ozone $\left(\mathrm{O}_{3}\right)$

- Carbon Monoxide (CO)

- Particulate Matter $\left(\mathrm{PM}_{2.5}\right)$

- Particulate Matter $\left(\mathrm{PM}_{10}\right)$

\subsection{Sampling Procedure}

In-situ air pollutants were measured in the atmosphere within the study area. The sampling was conducted for three days within the port's environment and Eleme Junction (the control location). Parameters of Ozone $\left(\mathrm{O}_{3}\right)$, Carbon monoxide (CO), Nitrogen dioxide $\left(\mathrm{NO}_{2}\right)$, Particulate matter $\left(\mathrm{PM}_{2.5}\right.$ and $\left.\mathrm{PM}_{10}\right)$, and Sulphur dioxides $\left(\mathrm{SO}_{2}\right)$ were collected. The data were acquired at purposefully selected locations (WACT, Shore-base, NIS and NPA-inside Onne port's environment) using hand-held Aeroqual Gas analyzer, series 500 (Figure 2) and a hand-held Germin-300 Global Positioning System (GPS) device (Figure 3) to record the 


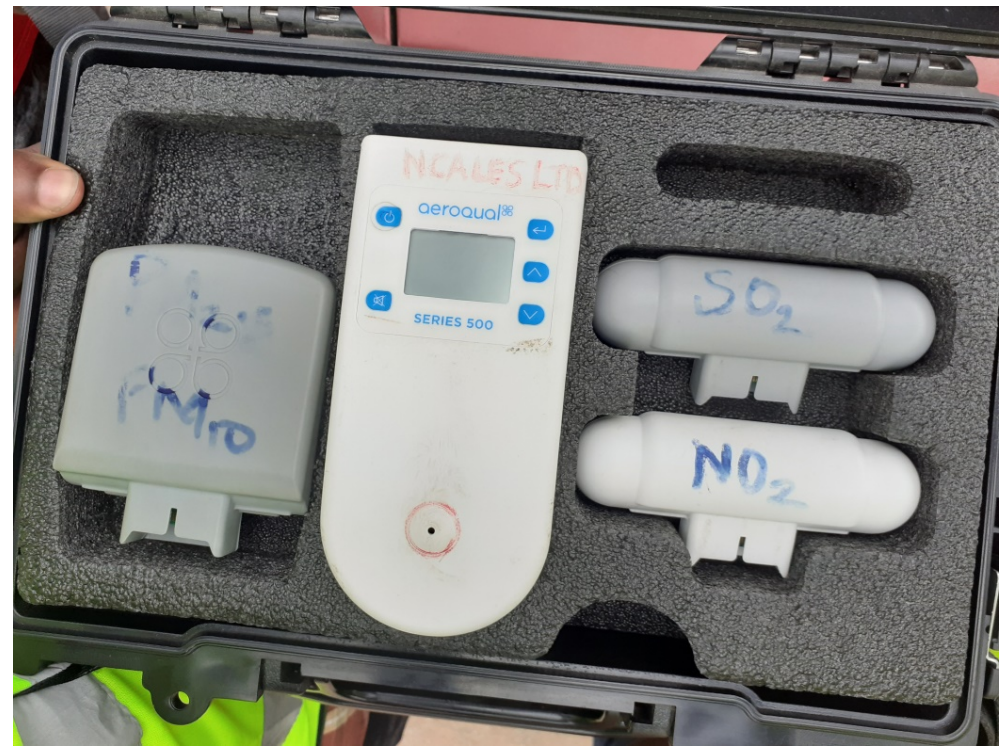

Figure 2. Pictorial view of hand-held Aeroqual gas monitor.

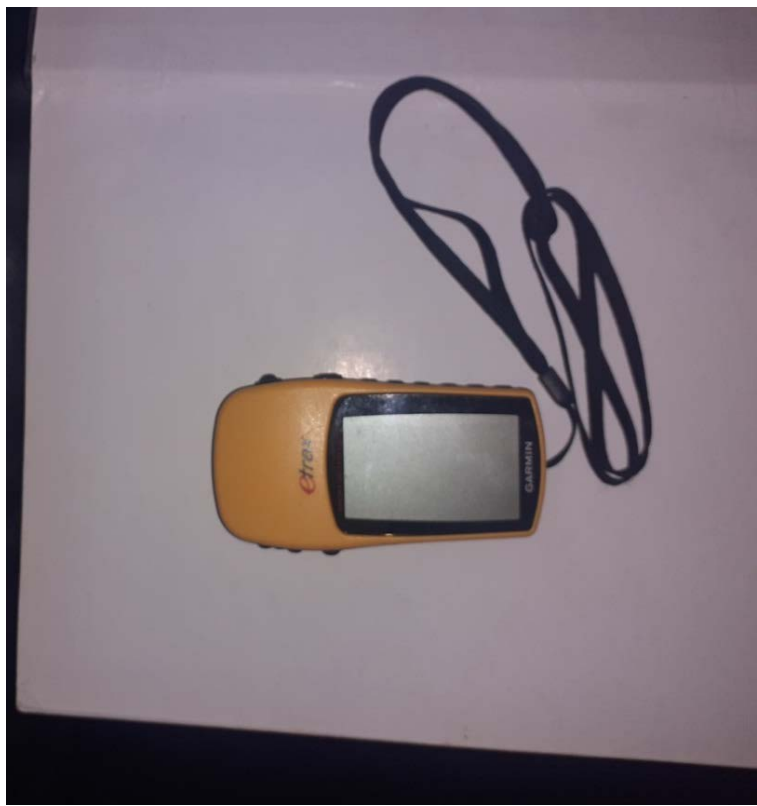

Figure 3. Pictorial view of the global positioning system (GPS), used for taking study area coordinates.

GPS coordinates of the sampling points for geospatial interpolation analysis using Arc Map 10.0.

\subsection{Atmospheric Pollutants Measurement}

Aeroqual 500 series gas analyzer was used to determine concentration of gases. The instrument is designed with NDIR (Non-dispersive Infrared) waveguide technology sensor. The instrument carried out automatic analysis of ambient air sampling of the physical properties that gives continuous output signal to the analyzer which returns the values (concentration) of gases under investigation, 
and which were recorded from the screen. The instrument has a wider range of measurements up to $150 \mathrm{~m}$ around the sampling area and can be held at arm's length. The instrument took 5 - 6 minutes to initialize, analyze and produce a given concentration of the pollutants under investigation. During the field work, Onne seaport was sampled for three (3) days at four (4) sampling locations during morning and afternoon periods. Similar steps were taken to obtain measurement for the control group at selected points around Eleme Junction-few kilometres from the port. The hours were chosen based on the meteorological hours recommended for weather observation by the World Meteorological Organization.

\subsection{Models for Data Analysis}

For analytical purposes, we consider the sample measurements in the port environment as the test group and that obtained at Eleme Junction as the control group. The object is to test for significant differences (if any) in vector of mean concentration $\left(\mu \mathrm{g} \cdot \mathrm{m}^{3}\right)$ of pollutants in the two groups-test and control. The vector of means comparisons would be carried out using Hotelling's $T^{2}$ statistic. Thereafter, Analysis of Variance (ANOVA) followed up with pairwise comparisons (Post-hoc analysis) will be applied for determination of differences and ranking of mean concentration of the constituent gases measured within Onne port and control location.

\subsubsection{Hotelling's $T^{2}$ Statistic}

According to NCSS.com (NCSS, [14]), the two-sample Hotelling's $T^{2}$ statistic is used to test the equality of the mean vectors of two populations. Specifically, suppose a set of $p$ response variables $Y_{1}, Y_{2}, \cdots, Y_{P}$ is measured for each of two groups. Assume that population 1 is distributed as $N_{p}\left(\mu_{1}, \Sigma_{1}\right)$ and population 2 is distributed as $N_{p}\left(\mu_{2}, \Sigma_{2}\right)$, where $N_{p}(\mu, \Sigma)$ is the $p$-variable multivariate normal distribution with mean vector $\mu$ and covariance matrix $\Sigma$. The null hypothesis that $\mu_{1}=\mu_{2}$ can be tested using the test statistic:

$$
T^{2}=\frac{n_{1} n_{2}}{n_{1}+n_{2}}\left(\bar{y}_{1}-\bar{y}_{2}\right) S_{p l}^{-1}\left(\bar{y}_{1}-\bar{y}_{2}\right)
$$

where $\bar{y}_{1}$ and $\bar{y}_{2}$ are the two sample mean vectors, $n_{1}$ and $n_{2}$ are the two sample sizes, and $S_{p l}^{-1}$ is the inverse of the pooled covariance matrix which is calculated using

$$
S_{p l}=\frac{\left(n_{1}-1\right) S_{1}+\left(n_{2}-1\right) S_{2}}{n_{1}+n_{2}-2}
$$

$S_{1} \& S_{2}$ are the estimated covariance matrices calculated from the two samples.

The $p$ response variables in our study are air pollutants $\left(\mu \mathrm{g} \cdot \mathrm{m}^{3}\right)$ namely: $\mathrm{O}_{3}$, $\mathrm{CO}, \mathrm{NO}_{2}, \mathrm{PM}_{2.5}, \mathrm{PM}_{10}$, \& $\mathrm{SO}_{2}$ measured in defined locations within Onne port's environment. These samples represent the test group (for purposes of statistical comparisons). The means of pollutants in the test group were compared with 
means $\left(\mu \mathrm{g} \cdot \mathrm{m}^{3}\right)$ of pollutants in the control group.

\section{Decision Rule:}

Under the null hypothesis

$$
F=\frac{n-k}{k(n-1)} T^{2} \sim F(k, n-k)
$$

where $n=n_{1}+n_{2}-1$.

If $F>F_{\text {crit }}$ then we reject the null hypothesis.

\subsubsection{ANOVA Model}

Analysis of Variance (ANOVA) is a method for testing the hypothesis that there is no difference between several population means (usually at least three) when there is only one qualitative variable which denotes the groups and only one measurement variable (quantitative). The ANOVA model was applied to test for statistically significant differences in mean concentration of pollutants and thereafter conduct post-hoc analyses.

Mathematically, ANOVA Model can be formulated as

$$
X_{i j}=\mu+\alpha_{i}+e_{i j} ; i=1,2, \cdots, k ; j=1,2, \cdots, n
$$

where: $X_{i j}=$ the measurement in the (ij)th cell.

$$
\begin{aligned}
\mu & =\text { grand mean } \\
\alpha_{i} & =\text { effect of the } i \text { th treatment } \\
e_{i j} & =\text { the error associated with } X_{i j} .
\end{aligned}
$$

Assumptions: $e_{i j} \sim N\left(0, \sigma^{2}\right)$

$$
\sum_{i}^{k} \alpha_{i}=0
$$

Hypothesis

$$
H_{0}: \alpha_{1}=\alpha_{2}=\alpha_{3}=\cdots=\alpha_{6}
$$

$H_{A}:$ at least $\alpha_{1} \neq 0$

$x_{i j}$ : Mean concentration of air pollutants

$i=1,2, \cdots, 6$ Pollutants in the study

$j=1,2,3, \cdots, n$ Locations

\section{Results Presentation}

\subsection{Level of Ambient Air Quality}

Six air pollutants, $\mathrm{O}_{3} \mathrm{CO}, \mathrm{NO}_{2}, \mathrm{PM}_{2.5}, \mathrm{PM}_{10}$, and $\mathrm{SO}_{2}$ were critically monitored. The descriptive statistics of these pollutants in ambient air measured across sample locations within Onne port (from day 1 - day 3) and the control are presented in Table 1 . As shown in Table 1, much variability was observed among these pollutants across the sampling days and locations. For example, the concentration $\left(\mu \mathrm{g} \cdot \mathrm{m}^{3}\right)$ of $\mathrm{O}_{3}, \mathrm{CO}, \mathrm{NO}_{2}$ and $\mathrm{SO}_{2}$ were $71.776 \pm 0.726,19.145 \pm 0.275$, $28.145 \pm 0.965$ and $36.913 \pm 0.378$ respectively while the particulates $\left(\mathrm{PM}_{10}\right.$, $\mathrm{PM}_{2.5}$ ) also showed some variations with $\mathrm{PM}_{10}$ increasing from 47.428 to 49.47 
Table 1. Descriptive statistics of mean concentrations $\left(\mu \mathrm{g} / \mathrm{m}^{3}\right)$ of Pollutants in Onne port and the control.

\begin{tabular}{|c|c|c|c|}
\hline Pollutants & Mean $( \pm$ s.e $)$ & $\min$ & $\max$ \\
\hline $\mathrm{O}_{3}$ & $71.776 \pm 0.726$ & 67.82 & 76.92 \\
\hline $\mathrm{CO}$ & $19.145 \pm 0.275$ & 17.741 & 21.279 \\
\hline $\mathrm{NO}_{2}$ & $28.145 \pm 0.965$ & 23.46 & 36.75 \\
\hline $\mathrm{PM}_{10}$ & $48.400 \pm 0.197$ & 47.428 & 49.47 \\
\hline $\mathrm{PM}_{2.5}$ & $29.676 \pm 0.352$ & 27.342 & 31.898 \\
\hline $\mathrm{SO}_{2}$ & $36.913 \pm 0.378$ & 34.39 & 38.38 \\
\hline \multicolumn{4}{|c|}{ Control (Eleme Jnc.) } \\
\hline $\mathrm{O}_{3}$ & $34.158 \pm 0.047$ & 33.86 & 34.44 \\
\hline $\mathrm{CO}$ & $12.218 \pm 0.0473$ & 11.88 & 12.47 \\
\hline $\mathrm{NO}_{2}$ & $22.467 \pm 0.158$ & 21.59 & 23.51 \\
\hline $\mathrm{PM}_{10}$ & $28.111 \pm 0.035$ & 27.95 & 28.34 \\
\hline $\mathrm{PM}_{2.5}$ & $21.550 \pm 0.170$ & 20.7 & 22.37 \\
\hline $\mathrm{SO}_{2}$ & $31.464 \pm 0.1664$ & 30.2 & 32.31 \\
\hline \multicolumn{4}{|c|}{ 2-group Hotelling's T-squared $=32,300.177$} \\
\hline \multicolumn{4}{|c|}{ F test statistic: $((24-6-1) /(24-2)(6)) \times 32,300.177=4,159.871$} \\
\hline \multicolumn{4}{|c|}{$\mathrm{H}_{0}$ : Vectors of means are equal for the two groups } \\
\hline \multicolumn{4}{|c|}{$\mathrm{F}(6,17)=4,159.871$, Prob. $>\mathrm{F}(6,17)=0.000$} \\
\hline
\end{tabular}

Source: Authors, data analysis.

$(48.400 \pm 0.197)\left(\mu \mathrm{g} \cdot \mathrm{m}^{3}\right)$, while concentration of $\mathrm{PM}_{2.5}$ increased from 27.342 to $31.898(29.676 \pm 0.352)\left(\mu \mathrm{g} \cdot \mathrm{m}^{3}\right)$. These variations can be attributed to ship, cargo and vehicular traffic movements within the port's environment. Variations in mean concentrations of pollutants were also observed in the control group. Significant variation of mean concentration of pollutants in the two groups was established through statistical test of differences of means in two groups. Thus as shown in Table 1, the Hotelling's $T^{2}$ statistic has a value of $32,300.177$, while the $F$ test statistic has $(4,159.871)$ a significant $p$ value of 0.000 . Thus, there is statistical evidence to show that means of pollutants differed in the two groups. The differences can be also inspected in Figure 4. This outcome provided basis for pairwise comparisons in further post-hoc analysis.

In Table 2, we observe significant differences through pairwise comparisons between the corresponding pairs of pollutants $\left(\mathrm{O}_{3}, \mathrm{CO}, \mathrm{NO}_{2}, \mathrm{PM}_{2.5}, \mathrm{PM}_{10}\right.$, and $\mathrm{SO}_{2}$ ) measured in the test and control groups. From the post hoc test results, we find that the mean concentration of each of pollutants was higher in the test group than in the control. The observed differences are significant according to $F$ statistic ( $p$ value $<0.000)$. When compared to the WHO standards, the mean concentrations of pollutants in the test group were also found to be higher than 


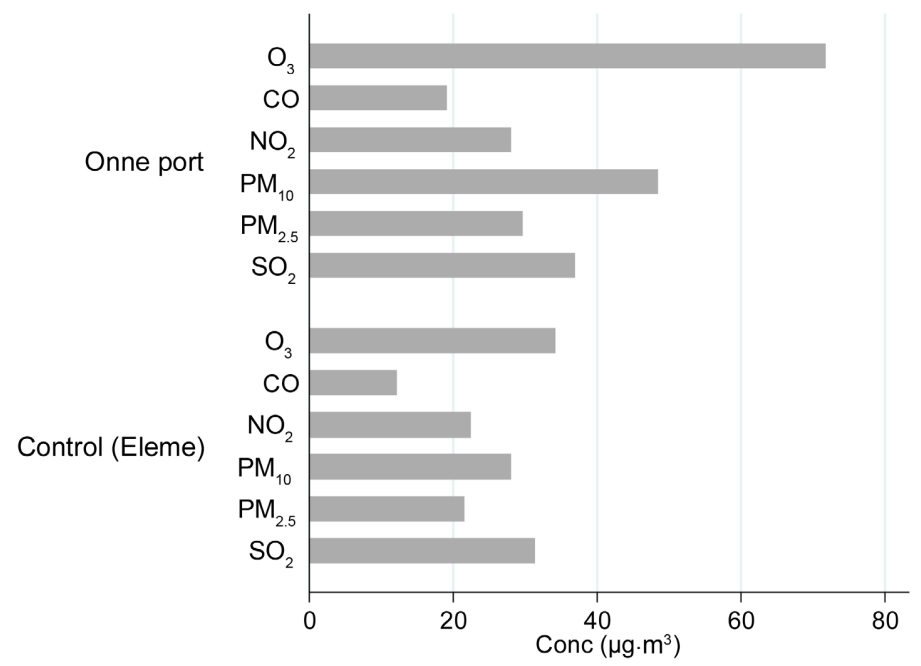

Figure 4. Bar chart showing difference in mean levels of concentration of pollutants in Test and Control groups.

Table 2. Pairwise comparisons of mean concentration $\left(\mu \mathrm{g} \cdot \mathrm{m}^{3}\right)$ of pollutants in test group with control \& WHO Stds.

\begin{tabular}{ccccccc}
\hline \multirow{2}{*}{ Location } & \multicolumn{6}{c}{ Parameters } \\
\cline { 2 - 7 } & $\mathrm{O}_{3}$ & $\mathrm{CO}$ & $\mathrm{NO}_{2}$ & $\mathrm{PM}_{10}$ & $\mathrm{PM}_{2.5}$ & $\mathrm{SO}_{2}$ \\
\hline & 71.776 & 19.145 & 28.145 & 48.400 & 29.676 & 36.913 \\
Onne port & \pm & \pm & \pm & \pm & \pm & \pm \\
& 0.726 & 0.275 & 0.965 & 0.197 & 0.352 & 0.378 \\
Eleme Jnc. & 34.158 & 12.218 & 22.467 & 28.111 & 21.550 & 31.464 \\
(Control) & \pm & \pm & \pm & \pm & \pm & \pm \\
& 0.047 & 0.0473 & 0.158 & 0.035 & 0.170 & 0.166 \\
F-test ( $p$ value $)$ & 0.000 & 0.000 & 0.000 & 0.000 & 0.000 & 0.000 \\
WHO Stds. & 60 & 4 & 25 & 45 & 15 & 40
\end{tabular}

Source: Authors, data analysis.

critical limits set by the WHO's 2021 guidelines (WHO [15]). Thus, in increasing order of magnitude, the following pollutants $\left(\mu \mathrm{g} \cdot \mathrm{m}^{3}\right)$ in ambient air measured in Onne port's environment, namely: $\mathrm{O}_{3}(71.776 \pm 0.726),>\mathrm{PM}_{10}$ (48.3999 $\pm 0.197),>\mathrm{SO}_{2}(36.913 \pm 0.378),>\mathrm{PM}_{2.5}(29.676 \pm 0.352),>\mathrm{NO}_{2}(28.145 \pm$ $0.965),>\mathrm{CO}(19.145 \pm 0.275)$ showed significant higher variations.

Thus, the observed significant emissions can be attributed to ships' port calls, vehicular movements and operation of heavy machinery within the port's environment. Other possible sources of emissions include automobile vehicles brought to the port by port users or trucks conveying goods to and from the quay aprons. As corroborated in existing study, a ship will on average emit 30 - 50 times more sulphur per ton-kilometre than a truck and ships release about twice as much $\mathrm{NO}_{\mathrm{x}}$ per ton-kilometre as the latest truck models (EEB, [16]).

For illustrative purposes, we present the distributions of vessel and cargo throughputs in Figure 5 \& Figure 6 and observe the positive trends in number 


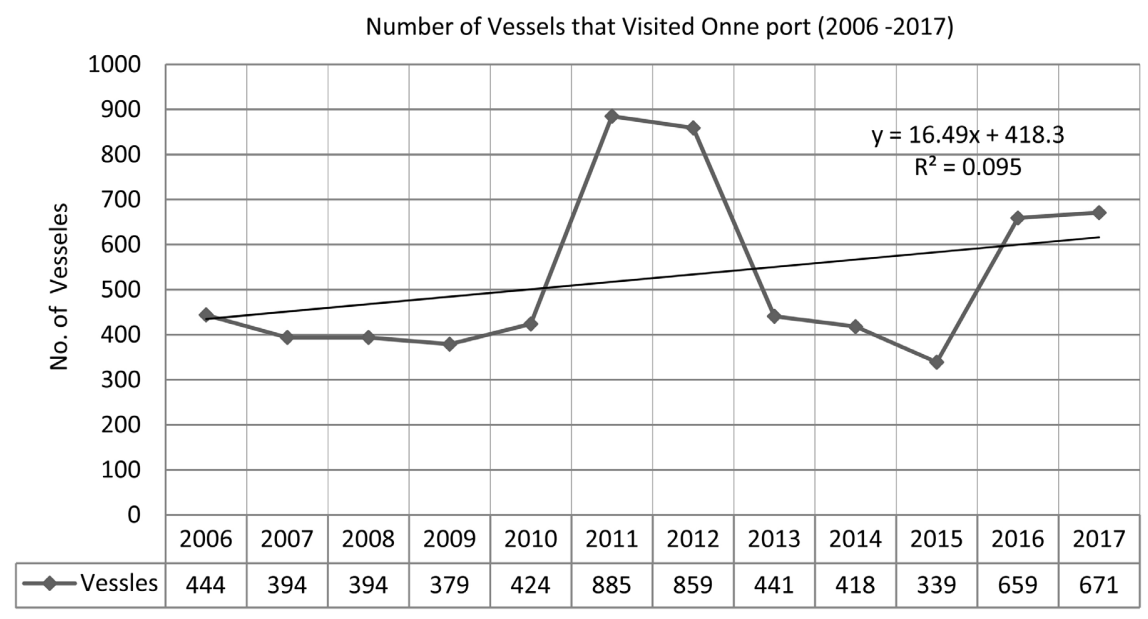

Figure 5. Trends in number of vessels that were handled in Onne port for the years 2006-2017.

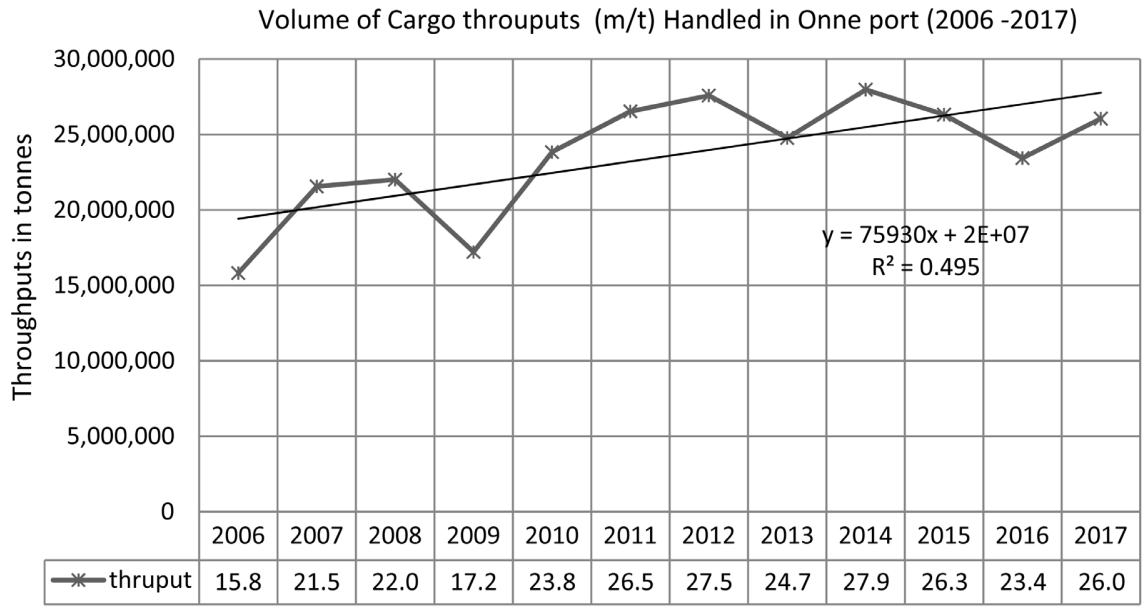

Figure 6. Trends in cargo throughputs handled in Onne port for the years 2006-2017.

of vessels well as volume of cargo throughputs handled in the same port over time. The cargo throughput levels can be taken as proxy for the number of trucks and locomotives that conveyed cargo to or from the port in that period. Since documented evidence shows that ship and cargo handling operations can give rise to pollutantion within the port environment, therefore, the observed profile of air pollutants exceeding control values and the WHO standards in this study can be attributed to number of visiting vessels, heavy goods trucks evacuating cargo and possibly mechanized cargo handling equipment.

\subsection{Discussion of Results}

The study investigated the parameters of air pollution at Onne seaport in River State. The mean concentration of ground level ozone $\left(\mathrm{O}_{3}\right)$, Carbon Monoxide (CO), Nitrogen dioxide $\left(\mathrm{NO}_{2}\right)$, fine $\left(\mathrm{PM}_{2.5}\right)$, \& coarse particulates $\left(\mathrm{PM}_{10}\right)$, and Sulphur dioxide $\left(\mathrm{SO}_{2}\right)$ were recorded across all the sampling points during the study period. Using statistical models, these were found to be significantly high- 
er than those measured in the control group. When compared with limits set by the WHO, all exceeded the safe permissible limits for gaseous pollutants. This exceedance could portend ecological hazards to residents, Flora and Fauna as elevated levels of these gaseous pollutants have been associated with chronic obstructive pulmonary diseases, asthma, tuberculosis (Ezzati \& Kamma, [17]), increased risk of liver failure, respiratory problems, skin disorders, neonatal deformities and other health risks (Odedrai et al., [18]). The observed high concentration of the pollutants can be attributed to the presence of several transport modes and equipment. Ships, cargo trucks, cranes, cargo handling equipment, all rail locomotives contribute to maritime related emission of air pollutants (Merico, et al., [19]).

\section{Conclusions}

The major findings of this study are that: the concentrations $\left(\mu \mathrm{g} \cdot \mathrm{m}^{3}\right)$ of gaseous pollutants $\left(\mathrm{O}_{3}, \mathrm{CO}, \mathrm{NO}_{2}\right.$ and $\left.\mathrm{SO}_{2}\right)$ and particulates: $\left(\mathrm{PM}_{2.5}, \mathrm{PM}_{10}\right)$ found in ambient air around Onne seaport were relatively higher than the control and the WHO's critical values. The elevated concentrations observed could be linked to maritime shipping operations; operations of several transport units such as ships, cargo trucks, cranes, cargo handling equipment, rail locomotives which contribute to maritime related pollutant emissions. These pollutants could pose health hazards to man and animal as well as toxicity to crops (Onwuegbuchunam, et al., [20]). The findings in this research raise questions on commitments and strategies so far implemented by the Nigerian Maritime Administration to comply with the IMO's MARPOL 73/78 Convention (Annex VI). Thus, in order to abate levels of air pollution emanating from anthropogenic activities within the port environment, we recommend the adoption of the following administrative instruments:

- The establishment of effective air quality management framework incorporating series of specific policy reforms and legislative changes to ensure sustainable environmental qualities. The Nigerian Maritime Administration and Safety Agency (NIMASA) should step up its enforcement of IMO's domesticated conventions on air pollution matters.

- The port management should provide shore-side electricity to ships at berths. This would encourage alternative energy use and reduce emissions from steaming vessels while in port.

- The government could also introduce environmental value added tax (EVAT) and strict laws to enforce use of available air pollution abatement technologies in ships visiting our ports.

- Nigeria being a signatory to IMO's convention for the Prevention of Marine Pollution (MARPOL 73/78) from ships, should ensure that vessels visiting Nigerian ports use sulphur free marine fuel or have scrubbers installed on their exhausts to reduce air pollution.

- Pricing incentives can also be offered to skippers that show demonstrable 
record of compliance to operational and technical provisions for containing ship-based air emissions while visiting Nigerian ports.

Future studies should consider a more disaggregate study on ambient air quality characteristics in all Nigerian ports. This will provide a more comprehensive picture given the differences in scale of maritime and other transport activities characteristic of our ports.

\section{Acknowledgements}

The authors wish to thank Dr. (Mrs.) T.E Ebe of the Department of Environmental Management, Federal University of Technology Owerri for her constructive criticisms which shaped the final outcome of this paper.

\section{Conflicts of Interest}

The authors declare no conflicts of interest regarding the publication of this paper.

\section{References}

[1] United Nations Conference on Trade and Development (UNCTAD) (2020) Review of Maritime Transport.

https://unctad.org/system/files/official-document/rmt2020_en.pdf

[2] Nicolae, F., Popa, C. and Beizadea, H. (2014) Shipping Air Pollution Assessment. Study Case on Port of Constanta. 14th International Multidisciplinary Scientific Geo Conference (SGEM), Constanța, Romania, 2014, 1-9.

https://www.researchgate.net/publication/278022990_Shipping_Air_Pollution_Asse ssment_Study_Case_on_Constanta_Port

[3] Bermudez, F.M., Laxe, F.G. and Aguayo-Lorenzo, E. (2019) Assessment of the Tools to Monitor Air Pollution in the Spanish Ports System. Air Quality, Atmosphere \& Health, 12, 651-659. https://doi.org/10.1007/s11869-019-00684-x

[4] Tokuslu, A. (2021) Estimation of Shipping Emissions in the Iskenderun Gulf, Turkey. International Journal of Global Warming, 23, 397-414. https://doi.org/10.1504/IJGW.2021.114345

[5] Eyring, V., et al. (2009) Transport Impacts on Atmosphere and Climate: Shipping, Atmospheric Environment.

[6] Song, S.K. and Shon, Z.H. (2014) Current and Future Emission Estimates of Exhaust Gases and Particles from Shipping at the Largest Port in Korea. Environmental Science and Pollution Research, 21, 6612-6622.

https://doi.org/10.1007/s11356-014-2569-5

[7] Olukanni, D.O. and Esu, O.C. (2018) Estimating Greenhouse Gas Emissions from Port Vessel Operations at the Lagos and Tin Can ports of Nigeria. Cogent Engineering, 5, 1507267. https://doi.org/10.1080/23311916.2018.1507267

[8] Smith, T.W.P., Jalkanen, J.P., Anderson, B.A., Corbett, J.J., Faber, J., Hanayama, S., O’Keeffe, E., Parker, S., Johansson, L., Aldous, L., Raucci, C., Traut, M., Ettinger, S., Nelissen, D., Lee, D.S., Ng, S., Agrawal, A., Winebrake, J.J., Hoen, M., Chesworth, S., Pandey, A. (2014) Third IMO GHG Study. International Maritime Organization (IMO) London, UK.

https://www.researchgate.net/publication/277889594_CO2_Targets_Trajectories_a nd_Trends_for_International_Shipping 
[9] IMO MEPC Resolution MEPC.213(63) (2012) 2012 Guidelines for the Development of a Ship Energy Efficiency Management Plan (SEEMP).

https://wwwcdn.imo.org/localresources/en/KnowledgeCentre/IndexofIMOResoluti ons/MEPCDocuments/MEPC.213(63).pdf

[10] Nwachukwu, A.N., Chukwuocha, E.O. and Igbudu, O. (2012) A Survey on the Effects of Air Pollution on Diseases of the People of Rivers Sate, Nigeria. African Journal of Environmental Science \& Technology, 6, 371-379.

https://doi.org/10.5897/AJEST12.024

[11] Olayimka, O.O., Adedeji, O.H. and Ajibola, F.O. (2015) Monitoring Gaseous and Particulate Air Pollutants Near Major Highways in Abeokuta, Nigeria. Journal of Applied Sciences and Environmental Management, 19, 751-758.

https://doi.org/10.4314/jasem.v19i4.23

[12] Abulude, O.F., Damodharan, U., Acha, S., Adamu, A. and Arifalo, K.M. (2021) Preliminary Assessment of Air Pollution Quality Levels of Lagos, Nigeria. Aerosol Science and Engineering, 5, 275-284. https://doi.org/10.1007/s41810-021-00099-1

[13] Jimoda, L.A., Odediran, E.T., Adebanjo, S.A., Ojetunji, O.E. and Lawal, O.L. (2017) Emission Inventory of Criteria of Air Pollutants from Tin-Can Island Seaport in Southern Nigeria. Nigerian Journal of Scientific Research, 16, 21-27.

https://journal.abu.edu.ng/index.php/njsr/article/view/201/198

[14] NCSS Statistical Software (2016) Hotelling's Two-Sample T2. https://ncss-wpengine.netdna-ssl.com/wp-content/themes/ncss/pdf/Procedures/NC SS/Hotellings_Two-Sample_T2.pdf

[15] World Health Organizations (WHO) (2021) Global Guidelines for Air Quality; Particulate Matter Ozone, Nitrogen Oxide, Sulphur Dioxide and Carbon Monoxide. https://apps.who.int/iris/bitstream/handle/10665/345329/9789240034228-eng.pdf?s equence $=1$ \&isAllowed $=\mathrm{y}$

[16] The European Environmental Bureau (EEB), Air Pollution from Ships (2004), The European Federation for Transport and Environment (T\&E) Seas at Risk (SAR). The Swedish NGO Secretariat on Acid Rain Updated November 2004. https://www.airclim.org/sites/default/files/documents/shipbriefing_nov04.pdf

[17] Ezzati, M. and Kammen, D.M. (2002) Household Energy, Indoor Air Pollution and Health in Developing Countries: Knowledge Base for Effective Interventions. Annual Reviews of Energy and the Environment, 27, 233-270. https://doi.org/10.1146/annurev.energy.27.122001.083440

[18] Odedrai, A., Burley, A., Lewis, A., Hardmanand, M. and Haynes, P. (2005) Oil Spill and Gas Flaring. Petroleum Geology Conference Series, 6, 577-587

[19] Merico, E., Cesari, D., Gregoris, E., Gambaro, A., Cordella, M. \& Contini, D. (2021) Shipping and Air Quality in Italian Port Cities: State-of-the-Art Analysis of Available Results of Estimated Impacts. Atmosphere, 12, 536. https://doi.org/10.3390/atmos12050536

[20] Onwuegbuchunam, D.E., Ebe, T.E., Okoroji, L.I. and Essien, A.E. (2017) Analysis of Ship-Source Marine Pollution in Nigeria Seaports. Journal of Marine Science and Engineering, 5, 39. https://doi.org/10.3390/jmse5030039 